\title{
EFFECTS OF INADEQUATE WATER SUPPLY TO THE COMMUNITY, WITH REFERENCE TO GIDAN KWANO IN NIGER STATE: A DESCRIPTIVE ANALYSIS
}

\author{
Yusuf Yahaya Miya ${ }^{1}$, Mustapha Usman Baba ${ }^{2}$, Muhammad Yusuf El-Tahir ${ }^{3}$, \\ Isyaku Rabiu ${ }^{4}$ and Ammani Muhammad Mukarram ${ }^{5}$ \\ ${ }^{1}$ Bauchi State Primary Health Care Development Agency. \\ yahayamiya@gmail.com \\ ${ }^{2}$ Department of Statistics, School of Technology, Kano State Polytechnic. \\ mubstatistics@kanopoly.edu.ng \\ ${ }^{3}$ Department of Statistics, School of Technology, Kano State Polytechnic. \\ eltahir202@gmail.com
}
${ }^{4}$ Department of Survey \& Geoinformatics, School of Environmental Studies, Kano State Polytechnic. isyakurabiu5@gmail.com

${ }^{5}$ Department of Quantity Survey, School of Environmental Studies, Kano State Polytechnic. ammukarram80@gmail.com

\begin{abstract}
It becomes imperative for a research to be conducted in this vein to help identify problems associated with inadequate water supply. This is to say that if we don't put in place effective water supply systems to support hygienic living, what is going to happen in the next 10 to 20 years would be uncontrolled infections. The research here-fore is significant as it helps in developing and implementing policies that will go a long way to help minimize the problems rural residence face as a result of inadequate water supply. And a greater percentage of the sampled household in Gidan Kwano (94\%) has their houses not connected to any public water supply. It was found that even commercial houses (lodges) connected to self-pipe borne do not guarantee that water will flow because of frequent power failure.
\end{abstract}

Keywords: Water Supply, Water Quality, Environment 


\section{Introduction}

Water is an indispensable resource for the world economy as well as a precondition for human, animal and plant life, as there can be no stability of health and well-being without safe and adequate water supply (Wilson, 1998). Water is not only a vital environmental factor to all forms of life, but it has a great role to play in socio-economic development for human population. The problem of potable water shortage has become a serious matter in the world from a local to a global perspective and has commanded a dramatic attention. 80 countries of the world now have water shortage and this is reflecting through their health and economies, while $40 \%$ of the World (more than 2 billion people) has no access to clean water or sanitation in the context (World Bank, 1996). According to WHO (1990), less than 50\% of the world's population has access to satisfactory water supply. This unhappy situation led the United Nation Assembly to declare year 1981-1990 a decade of international drinking-water supply and sanitation. This was geared towards the provision of clean drinking water for all by year 1990 (Olokesusi, 2004). The most important aspect of water shortage stems from water pollution, which is always created by human activities majorly through farming and agriculture. This comprises bush burning, use of fertilizer and pesticides, herbicides, fungicides and others which cause soil runoff into surface water and leaching into aquifers. In this way such chemicals percolate into the water-table and thereby make water unfit for drinking. According toFafioye and John-Dewole(2012), Industrial wastes are also discharged into the nearest waterway or into wastewater lagoon thereby reducing the level of the water dissolved oxygen (DO). Without sufficient oxygen, fish and other oxygen-consuming forms of aquatic life soon die. Another form of water pollution is organic wastes and chemicals such as oil, gasoline, detergent, and many other soluble and insoluble chemicals that threaten human health and harm fish and other aquatic life. Similarly, Gidan Kwano is suffering from inadequate water supply due to urbanization and landform. Solid wastes such as refuse from household are being disposed off indiscriminately into the streams, drainages and open places; the liquid waste is also discharged into surface water(Akpala, 2006). In the community, water from domestic sewages such as fasces, cassava wastewater and animal waste are the major causes of sickness and death each day. The kind of water related diseases that are manifested in the area include: diarrhea, malaria (majorly), measles, typhoid fever, cholera, Shigellosis, polio, meningitis, hepatitis A\&B, dysentery and pneumonia. Regrettably, infants, children and people with weakened immune systems are the most affected (Oyesiku, 2009).

\section{Scope of the Study:}

The study is restricted to the geographical boundary of Gidan Kwano Village in Bosso LGA in Niger State. The study will identify the causes and effect of inadequate water supply. The study is focused on Gidan Kwano village which is about $13.4 \mathrm{~km}$ from central Minna. It lies within the coordinates $9^{\circ} 32^{\prime} 27.01 \mathrm{~N}$ and $9^{\circ} 32^{\prime} 27.02 \mathrm{~N}, 6^{\circ} 28^{\prime} 31.59 \mathrm{E}$, and $6^{\circ} 28^{\prime} 29.39 \mathrm{E}$, in direct opposite of Federal University of Technology Minna, which is located along the MinnaKataeregi-Bida road. It is bounded by Gidan Mangoro village at the North and Garatu village at the south. Gidan Kwano is accessed by an express way which links Minna and Bida towns. It is located in Bosso Local Government Area of Niger State, which is a North Central State of Nigeria. 


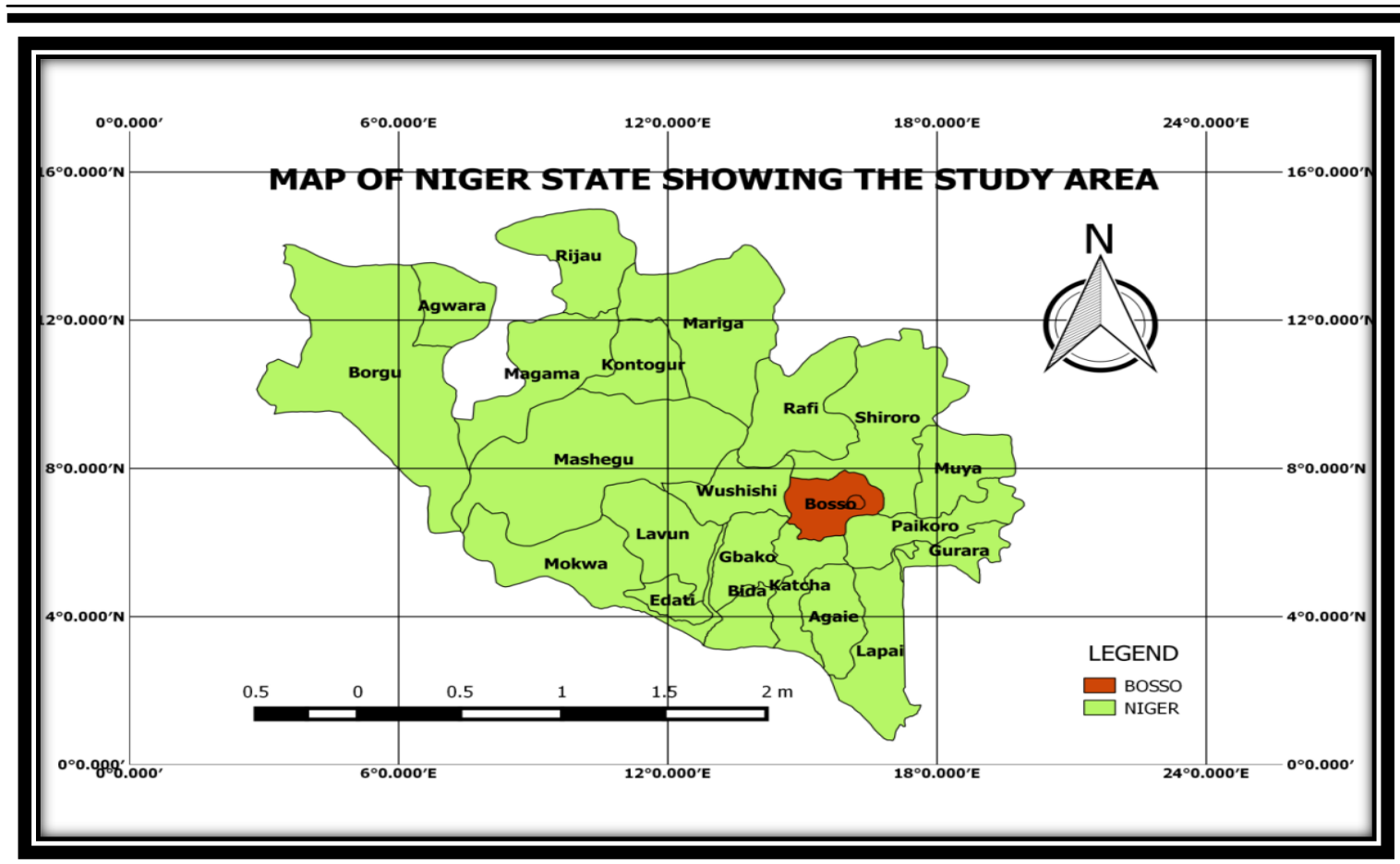

Fig. 1: Map of Niger State showing Bosso Local Government Area.

\section{Material \& Method}

In this study, survey research method will be used to assess the effects of inadequate water supply on human health by analyzing the location-based differential effect of the phenomenon on human health, this involves selecting portion out of the group of the entire population available for the study as the representative. The portion will then be used as the sample size in which necessary data for the research will be obtained and analyzed. 
Table 3.2: Showing summary of research methods

\begin{tabular}{|c|c|c|c|c|c|}
\hline $\mathbf{S} / \mathbf{N}$ & $\begin{array}{l}\text { OBJECTIVES } \\
\text { OF THE } \\
\text { STUDY }\end{array}$ & $\begin{array}{l}\text { TYPES OF } \\
\text { DATA } \\
\text { REQUIRED }\end{array}$ & $\begin{array}{l}\text { INSTRUMENT } \\
\text { OF DATA } \\
\text { COLLECTION }\end{array}$ & $\begin{array}{l}\text { METHOD } \\
\text { OF DATA } \\
\text { ANALYSIS }\end{array}$ & $\begin{array}{l}\text { METHOD OF } \\
\text { DATA } \\
\text { PRESENTATION }\end{array}$ \\
\hline 1 & $\begin{array}{l}\text { To assess the } \\
\text { effects of } \\
\text { inadequate } \\
\text { clean and } \\
\text { wholesome } \\
\text { water supply }\end{array}$ & $\begin{array}{l}\text { Scarcity of } \\
\text { water. } \\
\text { Water infection, } \\
\text { Unhealthy well } \\
\text { being, } \\
\text { Environmental } \\
\text { pollution. }\end{array}$ & Questionnaire & $\begin{array}{l}\text { Descriptive } \\
\text { analysis }\end{array}$ & $\begin{array}{l}\text { Frequency table } \\
\text { percentages } \\
\text { Bar chart }\end{array}$ \\
\hline 2 & $\begin{array}{l}\text { To determine } \\
\text { the causes of } \\
\text { water shortage } \\
\text { in study area. }\end{array}$ & $\begin{array}{l}\text { Seasonal defect, } \\
\text { Water misuse, } \\
\text { Inadequate } \\
\text { facility. }\end{array}$ & Questionnaire & $\begin{array}{l}\text { Descriptive } \\
\text { analysis }\end{array}$ & $\begin{array}{l}\text { Frequency table } \\
\text { percentages } \\
\text { Bar chart }\end{array}$ \\
\hline 3 & $\begin{array}{l}\text { To raise } \\
\text { awareness of } \\
\text { residents on the } \\
\text { importance of } \\
\text { adequate and } \\
\text { clean } \\
\text { wholesome } \\
\text { water supply so } \\
\text { as to improve } \\
\text { their living } \\
\text { conditions. }\end{array}$ & $\begin{array}{l}\text { Sanitization. } \\
\text { Maintenance } \\
\text { culture. } \\
\text { Health impact, } \\
\text { Domestic, } \\
\text { industrial \& } \\
\text { agricultural use }\end{array}$ & Questionnaire & $\begin{array}{l}\text { Descriptive } \\
\text { analysis }\end{array}$ & $\begin{array}{l}\text { Frequency table } \\
\text { Percentage } \\
\text { Bar chart }\end{array}$ \\
\hline
\end{tabular}

\section{Primary Source of Data}

The types of primary data to be collected are the effects of inadequate water supply e.g. water pollution, scarcity of water, water infection, utilities like pipe borne, boreholes and reservoir. Others are sanitization and maintenance culture.

\section{Sample Size}

This is the total number of people the questionnaire will be administered to for the purpose of acquiring information relevant for this study using the sample size formula.

Sample size $=\frac{N}{1+N(\mathrm{e})^{2}}$

Where $\mathrm{N}=$ Total Household number, which is $133, \mathrm{e}=$ degree of freedom which is $(0.05)^{2}$ 
Therefore, the sample size of the study is;

Sample size $=\frac{133}{1+133(0.05)^{2}}=100$

Sample size $=100$

Therefore 100 questionnaires will be distributed.

\section{Sampling Techniques}

The sampling technique to be adopted for this study is probability sampling techniques. The probability sampling technique to be used will be simple random sampling technique as it provides equal opportunity to every member of the sample size.

\section{RESULTS \& DISCUSSION}

\section{Demographic Information of The Respondent}

Field survey analysis shows that about $66 \%$ of the people involved in getting water for the household are mostly women (fig. below), this is because women are usually in domestic activities than men.

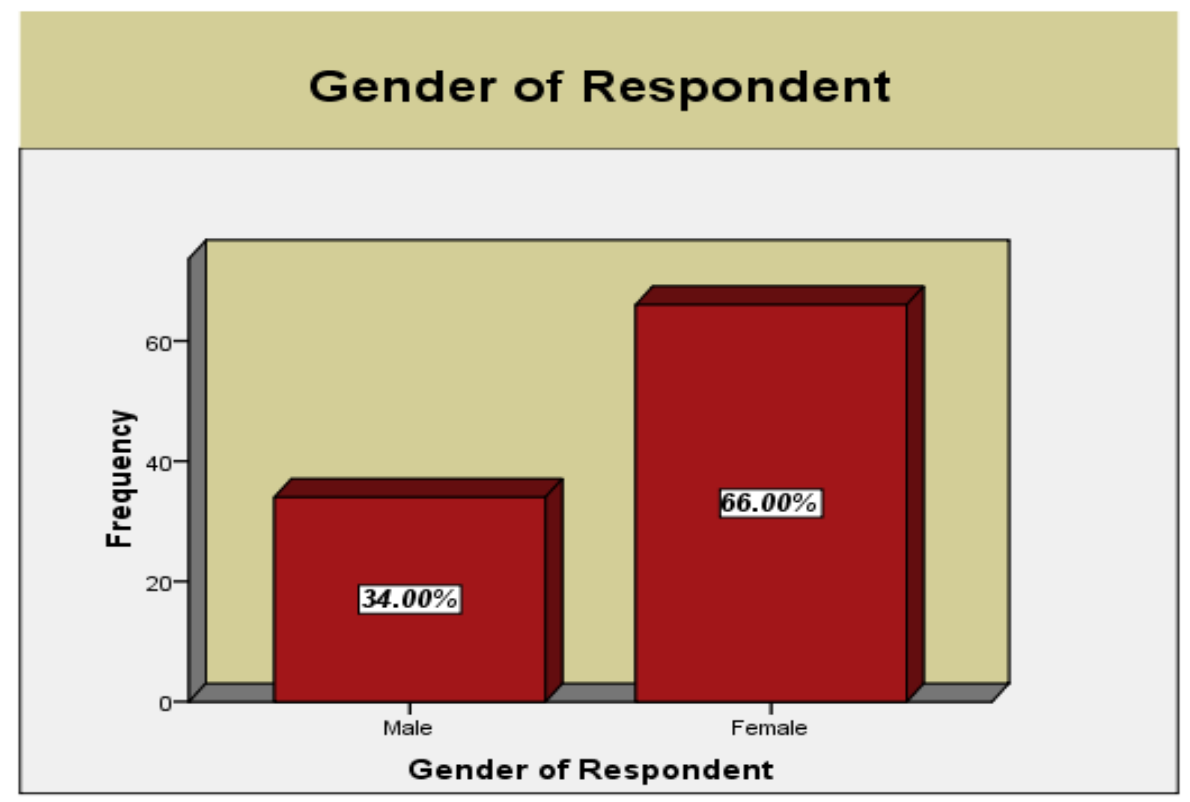

Fig. 2: Showing the gender of the respondents

\section{Marital Status}

The field survey reveals in the (Fig. 3) that about $66 \%$ of the people in the study area are married, and this has played a better role in determining the ways of communication, interaction and interrelationship among the people in the study area. 


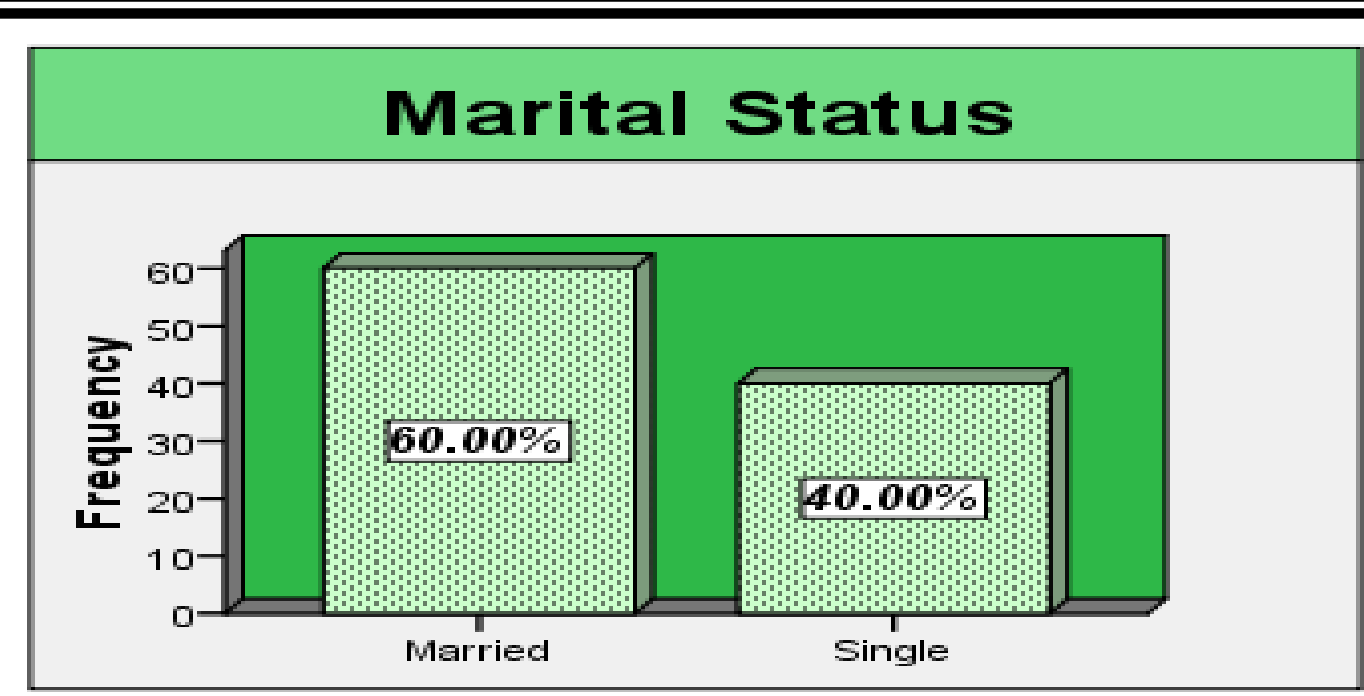

Fig. 3: Showing the marital status of the respondents

\section{Household Size}

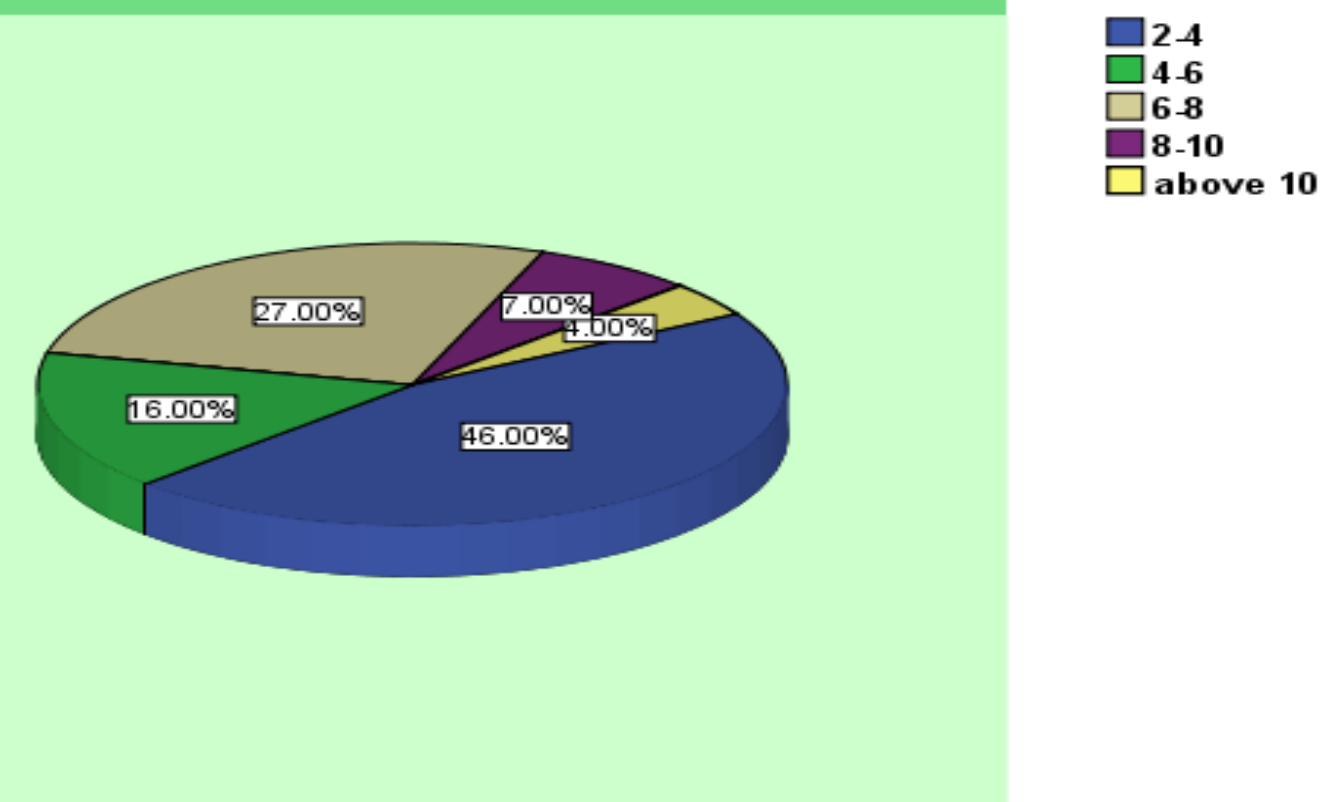

Fig.4: Showing the household size of the respondents 


\section{Educational Status}

Field data revealed that $50 \%$ of the indigenes and $24 \%$ of the tertiary students involved in the use of water in the study area, it has shown that $50 \%$ are educated, and thus has make it a little easier to get vital information because they easily understand the effect and information about the inadequate water supply (Fig. 4).

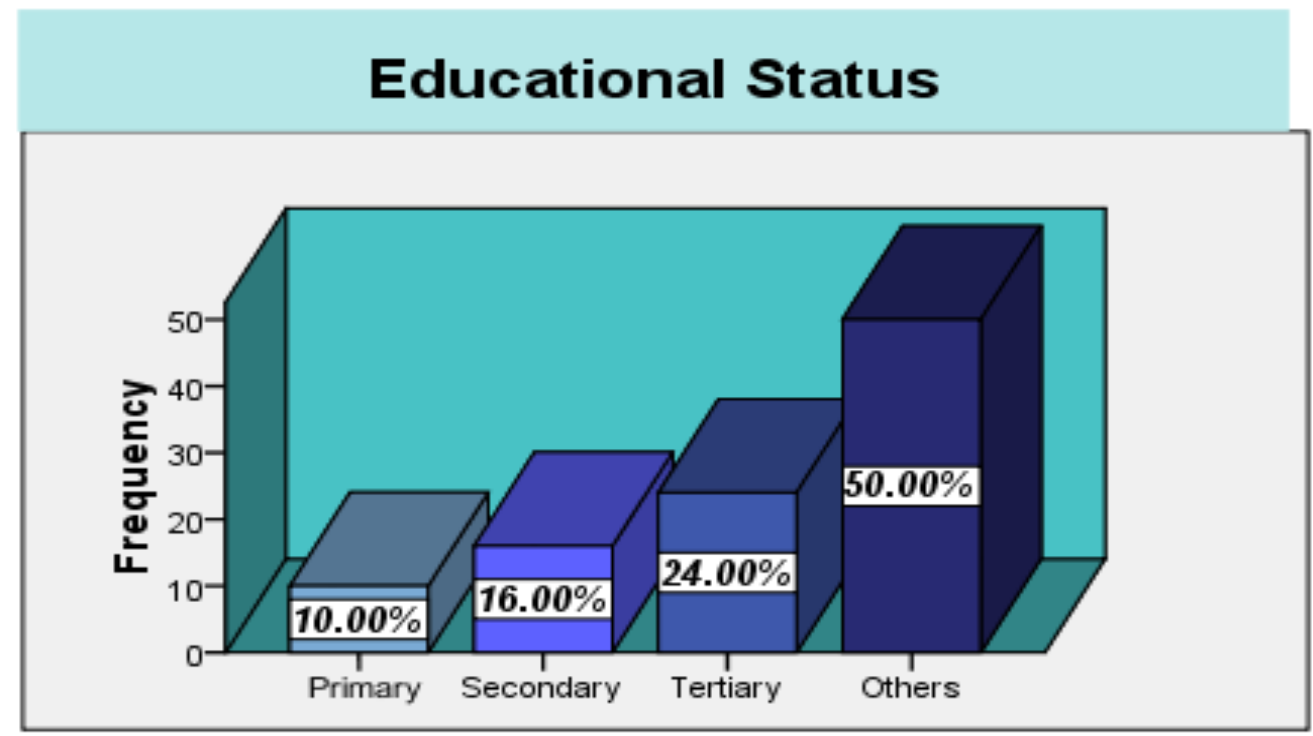

\section{Sources of Water Supply}

Field data revealed in fig. 5 shows that about $43 \%$ have their source of water from well, $27 \%$ from borehole, $21 \%$ from the stream, and $9 \%$ from pipe borne which are limited within the commercial residents (lodges).

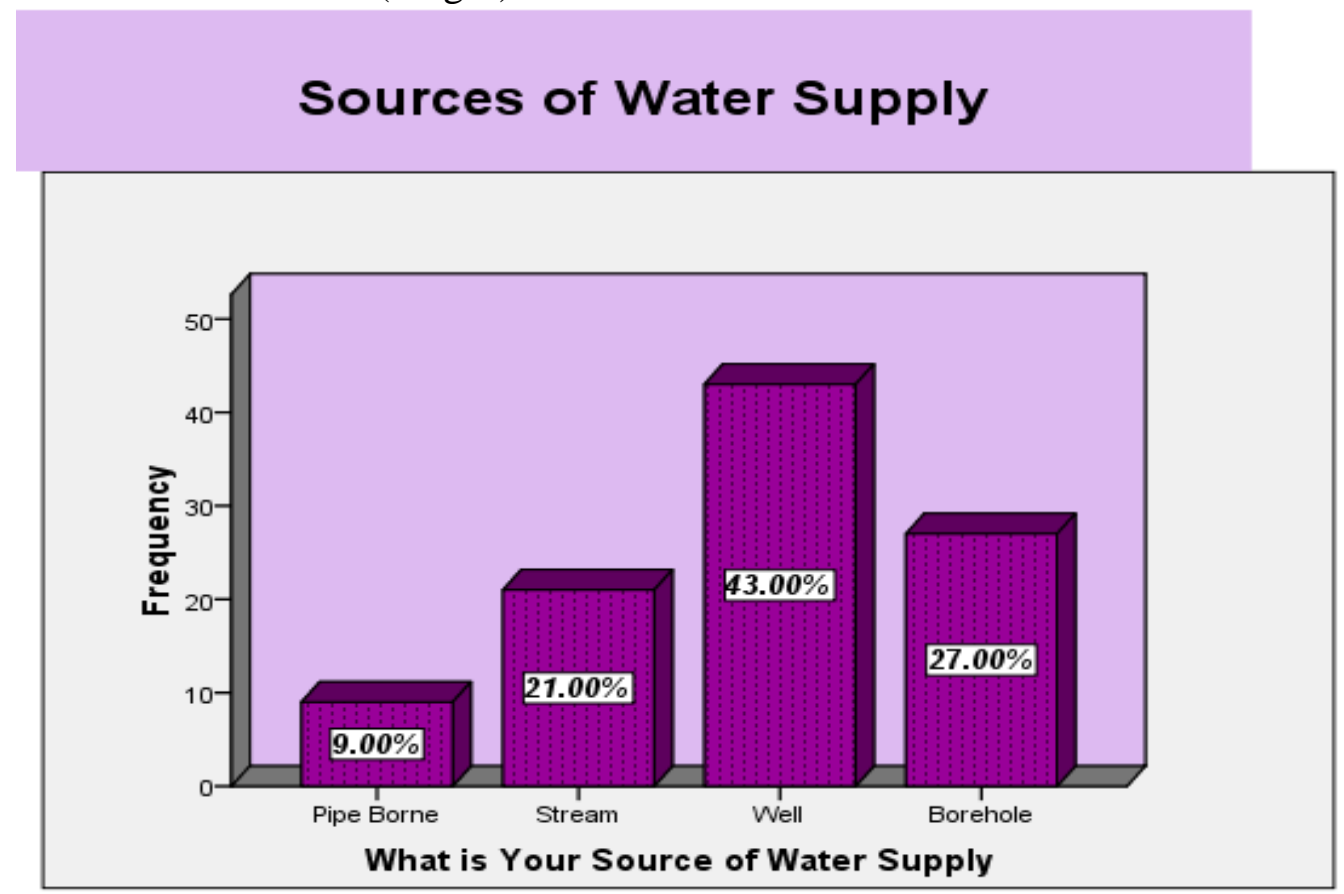

Fig. 5: Showing the source of water supply of the respondents, Field survey revealed the pictures below in plate 1 to 4 as the sources of water supply in the study area. 


\section{Liters of Water per Day}

The study revealed that about $60 \%$ of respondents use 15 liters of water per day while $10 \%$ of respondents use 10 liters per day, 20\% among the respondents use 11 liters of water per day and $10 \%$ among the respondents use 8 liters of water per day.

\section{Inadequate Water Supply Lead to Infection}

The frequency table below shows that $56 \%$ of the respondents strongly agreed that inadequate and unwholesome water supply resulted to disease such as scabies and other water washed disease infections from polluted water around the area. Most of the infected people are children because of their closeness to polluted water.

Table 1: Inadequate water supply leads to infection

\begin{tabular}{ccccc}
\hline Response & $\begin{array}{c}\text { Frequenc } \\
\mathrm{y}(\boldsymbol{f})\end{array}$ & $\begin{array}{c}\text { Percent } \\
(\%)\end{array}$ & $\begin{array}{c}\text { Valid } \\
\text { Percent }\end{array}$ & $\begin{array}{c}\text { Cumulative } \\
\text { Percent }\end{array}$ \\
Disagree & $\mathbf{2}$ & 2 & 2 & 2 \\
Fairly & 2 & 2 & 2 & 4 \\
Agree & 40 & 40 & 40 & 44 \\
$\begin{array}{c}\text { Strongly } \\
\text { Agree }\end{array}$ & 56 & 56 & 56 & 100 \\
Total & 100 & 100 & 100 & \\
\hline
\end{tabular}

Source: field survey 2017

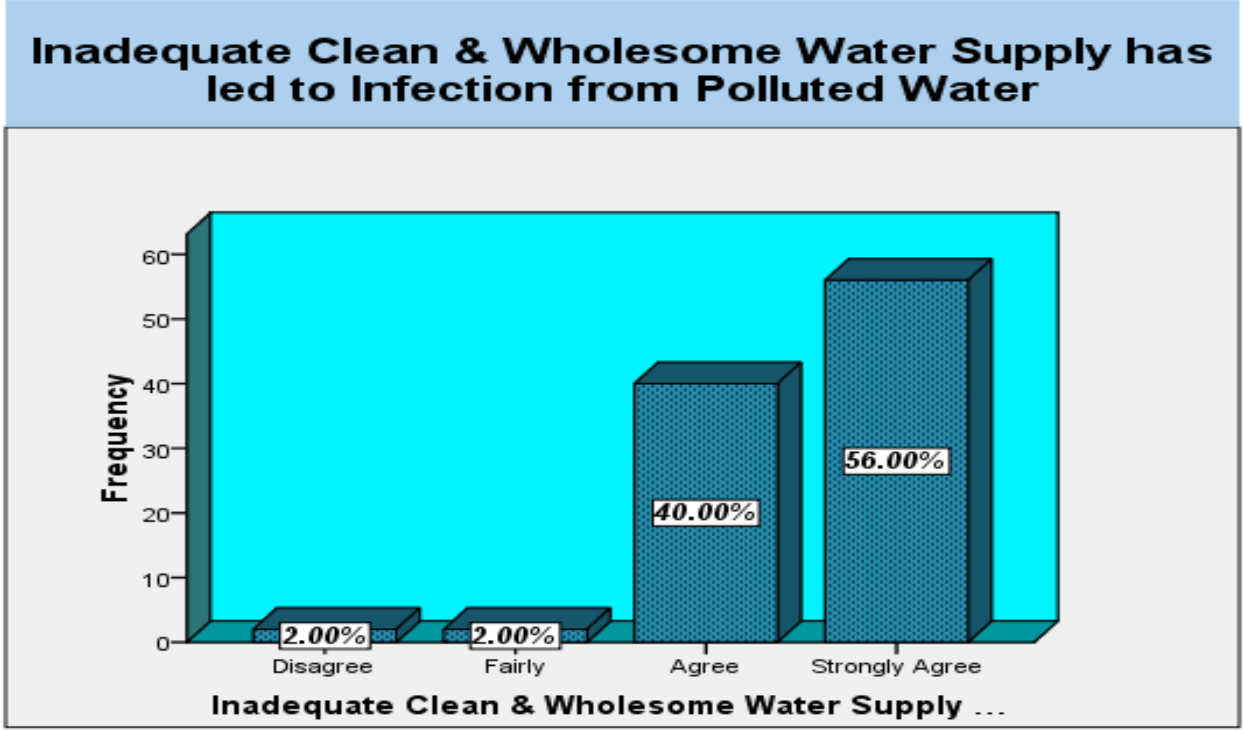

Fig. 6: Showing percent of infection from polluted water 


\section{Environmental Pollution Due To Unclean Water source}

The frequency table below shows that $44 \%$ and $40 \%$ (agreed and strongly agreed) were fairly on the same range on how unclean water polluted the environment they dwelled in.

Table 2: Environmental pollution due to inadequate water supply

\begin{tabular}{ccccc}
\hline Response & $\begin{array}{c}\text { Frequency } \\
(\boldsymbol{F})\end{array}$ & $\begin{array}{c}\text { Percent } \\
(\%)\end{array}$ & $\begin{array}{c}\text { Valid } \\
\text { Percent }\end{array}$ & $\begin{array}{c}\text { Cumulative } \\
\text { Percent }\end{array}$ \\
Disagree & 12 & 12 & 12 & 12 \\
Fairly & 4 & 4 & 4 & 16 \\
Agree & 44 & 40 & 40 & 56 \\
Strongly & & & & \\
Disagree & 40 & 44 & 44 & 100 \\
Total & 100 & 100 & 100 & \\
\hline
\end{tabular}

Source: field survey 2017

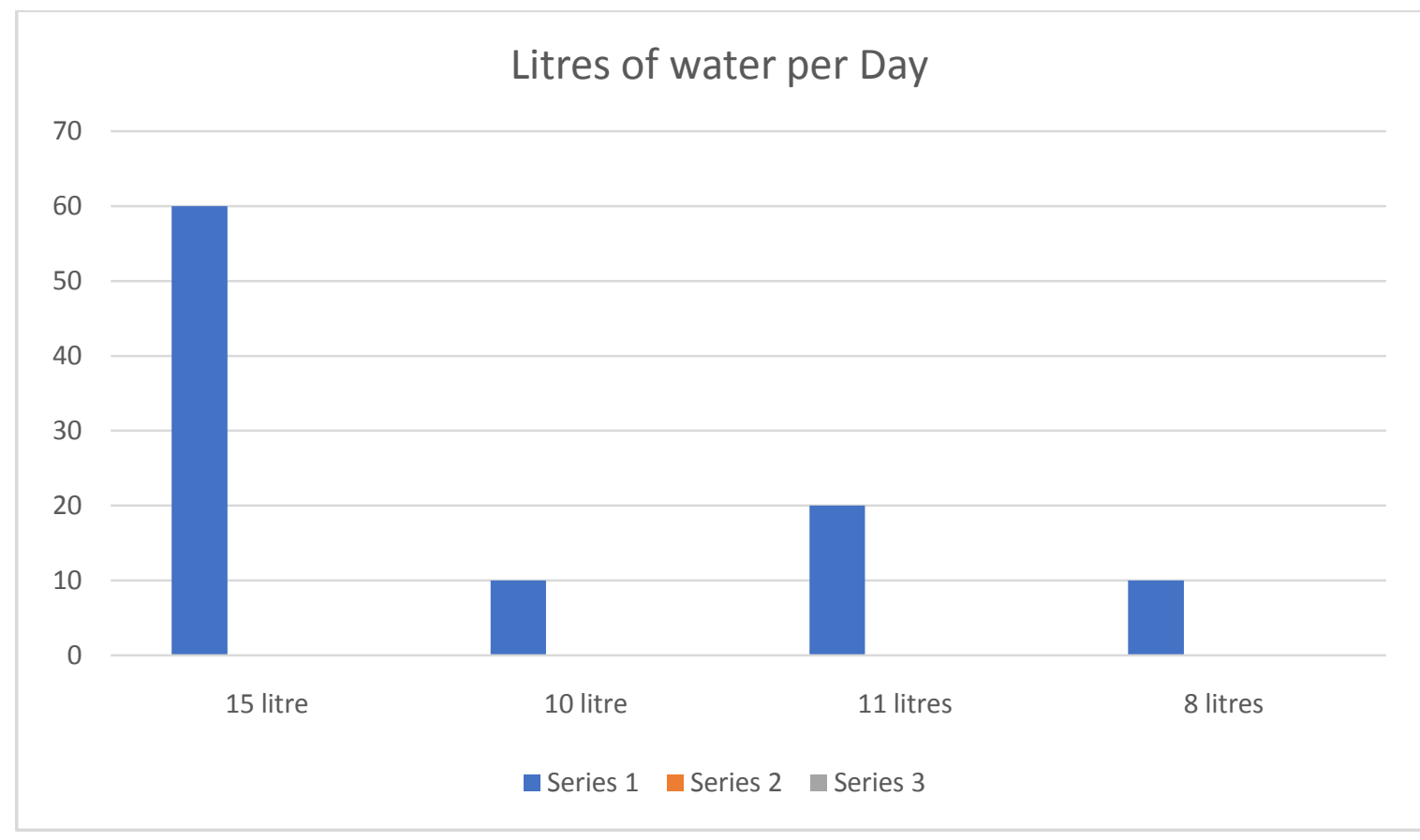

Fig. 5: Showing educational status of the respondents

\section{Effect of inadequate water supply on Human Well-Being}

Water from Wells, boreholes and pipe borne are mostly used domestically. This shows in the table below that inadequacy of getting water from these various sources affect their well-being within the households. 
Table 4: Effect of inadequate water supply on human well-being

\begin{tabular}{ccccc}
\hline Response & $\begin{array}{c}\text { Frequency } \\
(f)\end{array}$ & $\begin{array}{c}\text { Percent } \\
(\%)\end{array}$ & $\begin{array}{c}\text { Valid } \\
\text { Percent }\end{array}$ & $\begin{array}{c}\text { Cumulative } \\
\text { Percent }\end{array}$ \\
Disagree & 2 & 2 & 2 & 2 \\
Fairly & 5 & 5 & 5 & 7 \\
Agree & 69 & 69 & 69 & 76 \\
Strongly & 24 & 24 & 24 & 100 \\
Disagree & & & & \\
Total & 100 & 100 & 100 & \\
\hline
\end{tabular}

Source: field survey 2017

\section{Adequate Water Supply Improve Healthy Living}

In the table below, $48 \%, 32 \%$ and $14 \%$ (94\%) of the respondents generally agreed that adequate water supply improve healthy living but the Niger State government does not care about their source of water supply. $6 \%$ of the respondents generally disagreed because there was no government intervention about their sources of water supply and they still live healthy.

Table 6: Adequate water supply improves healthy living

\begin{tabular}{c|cccc}
\hline Response & $\begin{array}{c}\text { Frequency } \\
(f)\end{array}$ & $\begin{array}{c}\text { Percent } \\
(\%)\end{array}$ & $\begin{array}{c}\text { Valid } \\
\text { Percent }\end{array}$ & $\begin{array}{c}\text { Cumulative } \\
\text { Percent }\end{array}$ \\
Strongly & 2 & 2 & 2 & 2 \\
Disagree & & & & \\
Disagree & 4 & 4 & 4 & 6 \\
Fairly & 14 & 14 & 14 & 20 \\
Agree & 48 & 48 & 48 & 68 \\
Strongly & & & & \\
Agree & 32 & 32 & 32 & 100 \\
Total & 100 & 100 & 100 & \\
\hline Source: & & & & \\
\hline
\end{tabular}

Source: field survey 2017 


\section{Adequate Water Supply Improve Healthy Living}

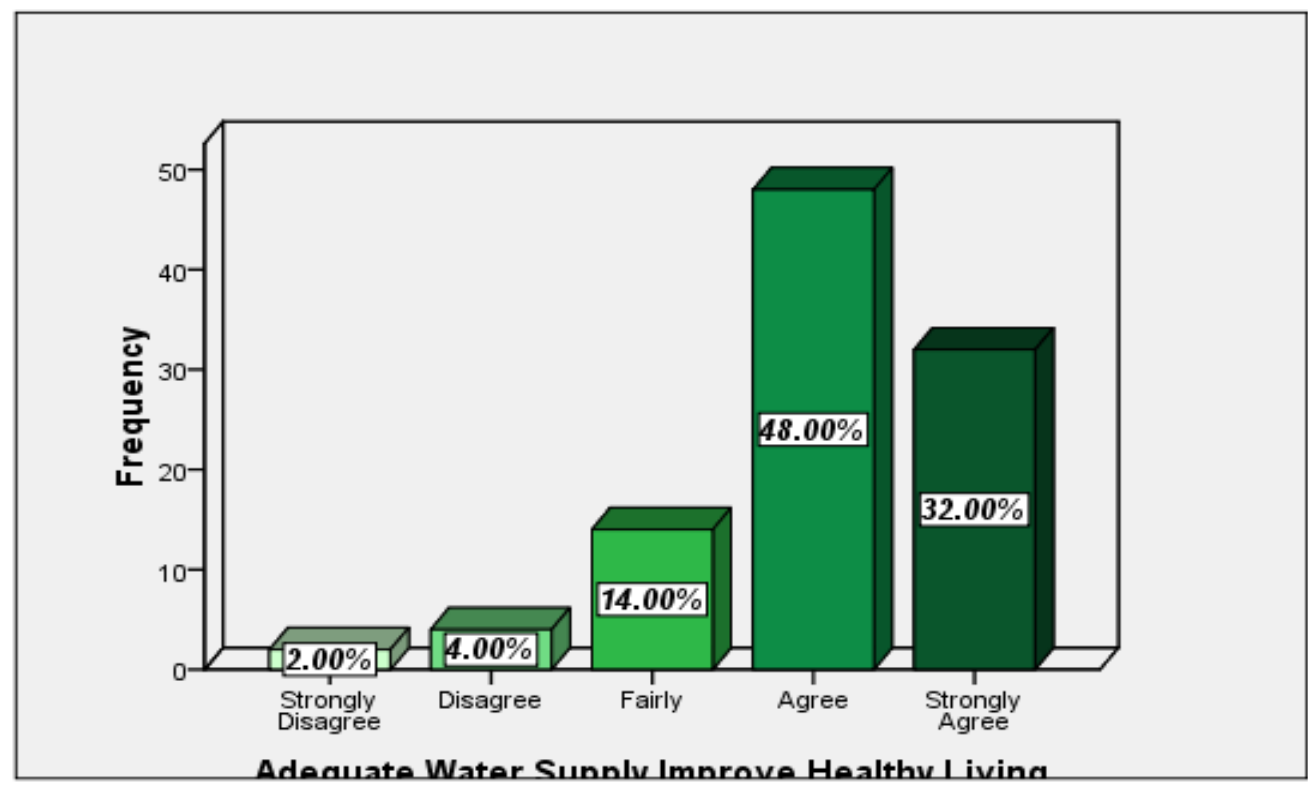

Fig. 5: Showing adequate water supply improve healthy living

\section{Summary \& Conclusion}

Water is seen as a major necessity in life of human beings. A good quality water supply is one that is adequate, accessible and reliable, and that is free from disease-causing organisms or chemical pollutants. Common water supply system in the study area include hand dug well, borehole and seasonal stream. Water related diseases include typhoid, cholera, dysentery caused by lack of hygiene of inadequate supply for drinking, bathing and washing, etc. From the foregoing analysis and discussion of finding in the preceding chapter of this study, it can be stated that:

Majority of people in Gidan Kwano lack adequate water supply therefore they get water from unhygienic source. Many obtain water from hand dug well, water-vendor and seasonal stream with bad quality which is unhealthy for human consumption. A greater percentage of the sampled household in Gidan Kwano (94\%) has their houses not connected to any public water supply. It was found that even commercial houses (lodges) connected to self-pipe borne do not guarantee that water will flow because of frequent power failure. The occurrence of water borne disease is affecting the health of people due to consumption of low-quality water obtained from unhygienic sources. 


\section{References}

Akpala, C. O. (2006): Health Implications of Poor Urban Planning In South-Eastern Nigeria; Journal of Environmental Research \& Managements. 3(4): 46 - 51.

Fafioye, O.O. And John-Dewole O.O. (2012b): Problem of Animal Wastes Disposal On The Environment; A Case Study Management Vol. 3(4). Pp. 084-087

Olokesusi, F. (2004): “An Assessment of Water-Supply Situation In Ecowas Countries And The Policy Implications”. J. Water Srt-Aqua, Vol. 19(7), No. 3, Pp. 152-160

Oyesiku, O.O. (2009): Nigerian Environmental Issues; A Statistical Approach. Journal of Environmental Research, Vol. 6(5). Pp. 14 - 21. UN, (2005), World Water Development Report I. Unicef, (2009).

Wilson, F. J. (1998): Making Wastes Work; A Strategy For Sustainable Development. Int'l Journal of Environmental Science \& Management. Vol. 6(8). 114 - 118.World Bank,

WHO (1990): Community Water Supply and Sanitation Proceedings of the Meeting of the Operation and Maintenance Working Group. Geneva June, 1990. Vol. 1 and 2.

World Bank, (1996): Nigeria; Poverty In The Midst Of Plenty - The Challenge Of Inclusion. Population and Human Resources Division, West Africa Department, World Bank, Washington, D.C. 